\title{
Maps Matter. The 10/40 Window and Missionary Geography
}

\author{
Hannah de Korte and David Onnekink \\ Utrecht University, Utrecht, the Netherlands \\ J.A.H.DeKorte@uu.nl \\ D.M.L.Onnekink@uu.nl
}

\begin{abstract}
The 10/40 Window map is used by evangelical missionary societies to promote mission in Northern Africa, the Middle East and South East Asia. It has been widely popular among Christians worldwide, but has also suffered sustained criticism. The map itself, however, has received no scholarly attention. This article investigates the 10/40 Window map through the lens of the concept of territoriality. Using insights from the field of critical cartography, it argues that the map is pivotal in directing missionary zeal, but that in turn it has also reshaped missionary thinking. This is so because the actual map's metageographical proportions, its cartographic language and the accompanying rhetoric communicate several novel key propositions about mission. The overall argument of this article is that maps are not innocuous illustrations, but indeed that maps matter a great deal and that missionary geography should be taken seriously.
\end{abstract}

\section{Keywords}

10/40 Window - global Christianity - territoriality - evangelicals - missionary cartography - global mission

\section{Introduction}

During the opening session of the Lausanne II conference in Manila in July 1989, the Argentina-born US missionary strategist Luis Bush launched his 10/40 Window concept. "The core of the unreached people of our world," he wrote, "live in a rectangular-shaped window," enclosed by the 10 and 40 


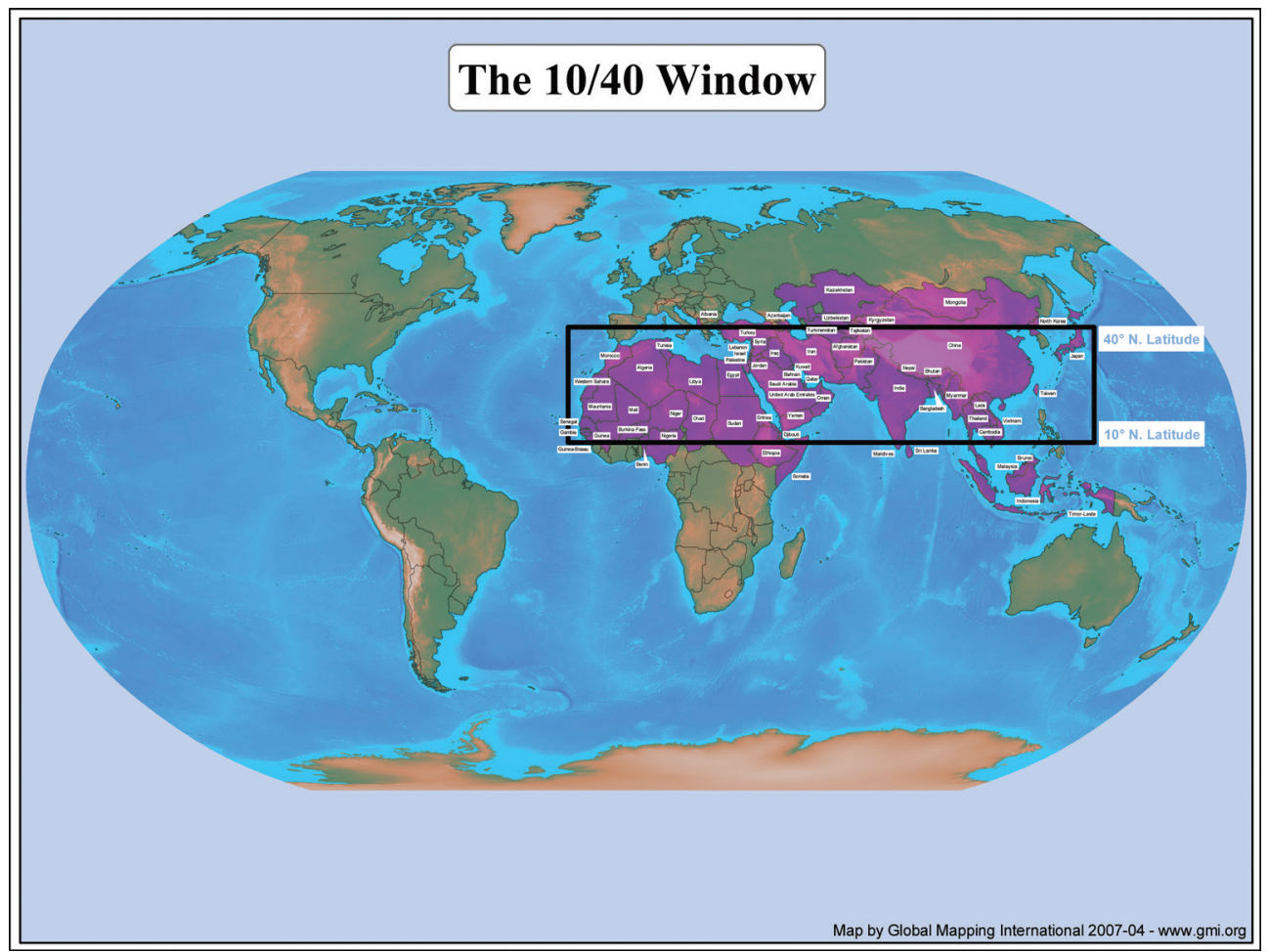

FIGURE 1 The 10/40 Window

SOURCE: HTTPS://WWW.MISSIONINFOBANK.ORG/. REPRODUCED WITH PERMISSION FROM MISSION INFO BANK

degrees latitude lines north of the equator [FIGURE 1]. This is a densely populated region of the world dominated by poverty, underdevelopment, and nonChristian world religions. ${ }^{1}$ Bush argued that this was the target area for global mission in the context of the upcoming millennium. The concept caught on with evangelicals worldwide and became the overarching framework of global mission in the decade leading up to the new millennium.

The Window has been criticized from three different perspectives. Firstly, several evangelical authors and missionaries complained that the Window marginalized mission outside the Window area, was Western-centric in its approach, and fueled tensions on the ground between Christians and members

1 Luis Bush, "Reaching the Core of the Core," Renewal Journal 10 (n.d.), 451; Melani McAlister, The Kingdom of God has no borders. A global history of American evangelicals (Oxford: Oxford University Press, 2018), chapter 8. 
of other religions in the Window area. ${ }^{2}$ Secondly, the Window converged uncomfortably with the political geography of US foreign policy in the 1990s and 20oos, identifying the Middle East and Islam as problem areas. ${ }^{3}$ In the view of anthropologist and theologian Michael Rynkiewich, "The concepts of the 10/40 Window, AD2000 and the Joshua Project resonate with the larger American Evangelical rhetorical vision in which organizational and military language is blended with religious language to form a view of how America fits

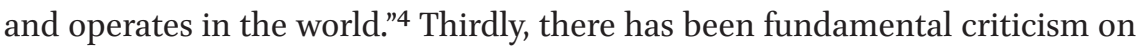
the anthropological building blocks of the Window: the notion of 'unreached people groups' (UPG) in the Window, groups defined by "various combinations of ethnicity, language, religion, caste and geography." ${ }^{5}$ According to cultural geographer Ju Hui Judy Han, such a "doctrine of racial typology and classification has little support in contemporary social science." 6

Literature on the 10/40 Window is scant; most scholarship on American mission mentions the Window only in passing and general studies on Global Christianity tend to ignore the Window altogether. ${ }^{7}$ Moreover, the actual 10/40 Window map has been strangely overlooked, even though it visualizes the

2 McAlister, The Kingdom of God has no borders, 152-3, 158.

3 Hannes Gerhardt, "The problematic synergy between evangelicals and the U.S. State in Sub-Saharan Africa," in Mapping the end times: American evangelical geopolitics and apocalyptic visions, (eds.). Jason Dittmer and Tristan Sturm (Farnham: CRC Press, 2010), 157-182. Cf. Marc Hujer et al., "Die Rückkehr des Allmächtigen," Der Spiegel 19 (2009).

4 Michael A. Rynkiewich, "Corporate metaphors and strategic thinking: 'The 10/40 Window' in the American evangelical worldview," Missiology: An International Review 35/2 (2007), 232; Lee Marsden, "Conservative evangelicals, the Tea Party and US foreign policy," in Obama and the world: new directions in US foreign policy, (eds.). I. Parmar et al. (Abingdon: Routledge, 2014), 120-122.

5 Definition cited by the Joshua Project on https://joshuaproject.net/resources/articles/what is_a_people_group. All URL's in this article double-checked 30 January 2020.

6 Ju Hui Judy Han, "Reaching the Unreached in the 10/40 Window: the missionary geoscience of race, difference and distance," in Mapping the End Times, (eds.). Dittmer 183-207. Cf. Rynkiewich, "Corporate metaphors," 222; Peter Lee and James Park, "Beyond people group thinking: A critical reevaluation of unreached people groups," Missiology: An International Review, 46 (2018), 212-225.

7 Most articles that mention the 10/40 Window do so only cursorily. Most general studies on Global Christianity do not mention the 10/40 Window at all: e.g. Lamin Sanneh, Disciples of all nations: pillars of world Christianity (Oxford: Oxford University Press, 2007); Mark Noll, The new shape of world Christianity: how American experience reflects global faith (Madison WI: InterVarsity Press, 2009); Brian Stanley, Christianity in the twentieth century: a world history (Princeton: Princeton University Press, 2018). Philip Jenkins, The next Christendom: the Coming of global Christianity (Oxford: Oxford University Press, 2002) mentions the Window in passing. 
chief and overarching conceptual and geographical framework..$^{8}$ It is not selfevident that missionary strategy centers around a map. According to Arthur Klinghoffer, it is noteworthy that, "In contrast to the Islamists, sponsors of the '10/40 window' do offer a cartographical vision of their project." ${ }^{\text {A Although the }}$ map can be interpreted as a visualization of missionary goals, we argue that the map itself has reconceptualized the way in which evangelicals think about the world. It has become a framework within which missionary goals are formulated and evangelical world views are reshaped.

We take our cue from methodologies developed within Human Geography, the discipline that studies the connectedness between society and space. ${ }^{10}$ Our point of departure is the concept of territoriality, defined by US geographer Robert D. Sack as "the attempt by an individual or group to affect, influence, or control people, phenomena, and relationships, by delimiting and asserting control over a geographic area [...] called a territory."11 As Ju Hui Judy Han observed, the 10/40 Window equipped evangelicals to "continue to embark on a territorialized strategy for world evangelization." ${ }^{12}$ In this article we analyse the function of the 10/40 Window map as a territorial device by applying critical cartography methodologies. This discipline was conceived by geographer Brian Harley in the 196os, who argued that "maps are part of a visual language by which specific interests, doctrines and even world views are communicated."13 More recently, some critical cartographers have departed from Harleyan cartography by denying that maps represent social reality in any way. According to Denis Wood, maps are entirely self-referential "systems of propositions" about the world. ${ }^{14}$ The function of critical cartography is to deconstruct the map and expose these propositions.

Our argument is that the use of the 10/40 Window map is a spatial missionary strategy to establish claims over territory. Our overall purpose is to show that maps matter: in understanding global missions or "dynamics of Christianities

8 In none of the articles mentioned above the actual map is discussed. An exception is Arthur Jay Klinghoffer, The power of projections: how maps reflect global politics and history (Westport CT: Greenwood Publishing Group, 20o6).

9 Klinghoffer, The power of projections, 132. Cf. Roger Stump, The geography of religion:faith, place, and space (Plymouth: Rowman and Littlefield Publishers, 2008), 82-83.

10 Paul Cloke et al. (eds.), Introducing human geographies (London and New York: Routledge, 2014), xvii.

11 R.D. Sack, Human territoriality: its theory and history (Cambridge: Cambridge University Press, 1986), 19.

12 Han, "Reaching the unreached," 201.

13 J.B. Harley, "Meaning and ambiguity in Tudor cartography," in English map-making 1500165o, (eds.). Sarah Tyacke (London: The British Library, 1983), 22.

14 Denis Wood, Rethinking the power of maps (New York: Guilford Press, 2010), 34, 51. 
worldwide," maps are not mere illustrations of, but are co-constitutive with, these dynamics. ${ }^{15}$ This chimes well with religious scholar Elizabeth McAlister's statement: "To study religion and place, space, territory, maps, or globalization means to join 'the spatial turn' in critical studies that would shift thinking 'from text to territory'"16 This article will use the insights of critical cartographers to deconstruct the 10/40 map. It will do so in three, connected, steps. The first step (section 3 ) is to investigate the nature of the 10/40 Window through what is known as meta-geography, the phenomenon of referring to large imaginary spaces (such as continents, or East and West) and imbue these with meaning. The second step (section 4) explores this in more detail by studying the actual 10/40 Window maps with methods generated by critical cartographers. The third step (section 5) in turn builds on both these sections by focusing on the nexus between image and text, concepts and phrases that are related to spatiality, through an investigation of the 'cartographic discourse' that is employed in connection with the 10/40 map. The three sections are preceded by a short outline of the genesis and development of the 10/40 Window map (section 2).

\section{The Genesis and Dissemination of the 10/40 Window Map}

Between 16 and 25 July 1974 evangelical leaders from all over the world met in Lausanne, Switzerland, at the International Congress of World Evangelization to discuss the necessity of, and strategy for, establishing a new impetus in world evangelism for "The Unfinished Task" of the Great Commission. The most important contribution at this convention was provided by Ralph D. Winter, one of the prominent figures of the Lausanne Movement, who pleaded for a focus within evangelism on "hidden," "frontier" or "unreached people groups" through "people group thinking."17 An unreached people group (UPG) can be defined as "a people group ${ }^{18}$ among which there is no indigenous community

15 The quote is from the mission statement of Exchange on https://brill.com/view/journals/ exch/exch-overview.xml.

16 Elizabeth McAlister, "Globalization and the religious production of space," Journal for the Scientific Study of Religion 44/3 (2005), 254.

17 Robert T. Coote, “AD 200o' and the '10/40 Window': a preliminary assessment," International Bulletin of Missionary Research 24/4 (2000), 161; Patrick Johnstone, "People groups: how many unreached?, International Journal of Frontier Missions 7/2 (1990), 3536; The Lausanne Movement, "The legacy of the Lausanne Movement," https://www.lau sanne.org/our-legacy.

18 A people group can be defined "as a significantly large sociological grouping of individuals who perceive themselves to have a common affinity for one another. From the viewpoint of evangelization this is the largest possible group within which the gospel can spread 
of believing Christians with adequate numbers and resources to evangelize this people group without outside (cross-cultural) assistance."19 Following Lausanne I, studies on people groups and unreached peoples took off. For example, with the computer revolution large quantities of information on peoples became increasingly available for statistical purposes. This led to the establishment of organizations such as the Mission Advanced Research Center (MARC), which produced a series of seven Unreached People Annuals between 1974 and 1987, and Global Mapping International (GMI), which developed maps and databases on global evangelization. Also, the editions of Operation World between 1974 and 1986 on the "unreached peoples of the world" were highly popular. ${ }^{20}$

A second International Congress of World Evangelization, Lausanne II, was held in Manila, the Philippines, from 11 to 20 July 1989. This follow-up convention paved the way for a more strategic framework for evangelization. Ever since Lausanne I, an increased feeling of urgency had informed the discussion on world evangelization to spread the Gospel amongst every unreached people group. With Lausanne II, the AD 2000 (\& Beyond) movement was kick-started with the goal of completing world evangelization by December 31, 200o, with Luis Bush as its international director. Building on Winter's concept of unreached people groups, Bush made a key contribution which shaped the strategic framework for world evangelization for the years to come.

In July 199o, Bush and Pete Holzmann "found that the great majority of nations with miniscule evangelical populations formed a band of about 60 countries with at least half their area lying between $10^{\circ}$ and $40^{\circ}$ latitude above the equator." According to Robert T. Coote, "Bush immediately saw the potential for a simple way to focus the Christian world's attention on the most Gospel-needy part of the globe." The 10/40 Window was promoted for the first time in the September-October 1990 issue of the organization's magazine $A D 2000$ and Beyond. ${ }^{21}$ However, from 1995 onwards more substantial writings and publications on the 10/40 Window appeared. According to Bush,

The 10/40 Window confronts us with several important considerations: first, the historical and biblical significance (according to Bush, Eden was once situated at the centre of the Window); second, the least evangelized

without encountering barriers of understanding or acceptance," see Edward R. Dayton and Samuel Wilson (eds.), The future of world evangelization (unreached peoples '84): The Lausanne Movement (Monrovia: World Vision International, 1984), 129.

19 Dayton and Wilson, The future of world evangelization, 129.

$20 \quad$ Johnstone, "People groups: how many unreached?," 35.

21 Coote, “'AD 200o' and the '10/40 Window', 162. 
countries; third, the dominance of three religious blocs; fourth, the preponderance of the poor; fifth, the unreached ethnolinguistic people groups; sixth, the least evangelized megacities; and seventh, the strongholds of Satan within the 10/40 Window. ${ }^{22}$

Because the countries that were incorporated in the Window differed over time, the respective statistics of Operation World on which the Window was based varied throughout the years. However, the 10/40 Window is mainly based on the idea that 37 of the world's 50 least-evangelized countries lie within the 10/40 Window. According to Bush, "Yet those 37 countries comprise $97 \%$ of the total population of the 5 o least evangelized countries! Such a fact leaves no doubt that our challenge in reaching the unreached must center on the core-the $10 / 40$ Window."23

The 10/40 Window gained momentum in the 199os, especially through the Joshua Project, an evangelical organisation that developed within the AD 2000 and Beyond movement in 1995 and is based in Colorado Springs. According to Melani McAlister, Professor of American and International Studies, it "was a sprawling, capacious, viral concept ... no one regulated it." ${ }^{24}$ Worldwide prayer campaigns reportedly mobilized millions of people praying for the 10/40 Window. ${ }^{25}$ Since the first decade of the new millennium, the Window appears to have lost some of its attraction. The Center for Global Christianity and Mission at Boston University has recently described the 10/40 Window as a "past model" for mission. ${ }^{26}$ In a recent interview, Jim Ramsay, Vice President of Global Operations of the TMs Global mission agency, stated that "I don't use terms like 10/40 Window anymore," explaining that the concept had become

22 Bush, "Reaching the core of the core", 451; Luis Bush, "The 10/40 Window: Getting to the core of the core", http://www.luisbushpapers.com/1040window/1996/10/22/1040-window -getting-to-the-core-of-the-core/.

23 Although the number of countries and the statistics on unreached people groups within the $10 / 40$ Window changed between 1990 and 1995, the percentage of $97 \%$ is still mentioned. Later on this percentage is reduced to approximately $61 \%$; Bush, "The $10 / 40$ Window"; Coote, “AD 200o' and the '10/40 Window', 162-163; Joshua Project, "What is the 10/40 Window?", https://joshuaproject.net/resources/articles/10_40_window.

24 McAlister, The Kingdom of God has no borders, 157-158.

25 Floyd McClung (eds.), Light the Window: Praying through the nations of the 10/40 window (Seattle: YWAM, 1999); see also John Lambert, 'Massive prayer and missions movements of the gos', 1 July 2014, http://www.missionfrontiers.org/issue/article/massive-prayer-and -missions-movements-of-the-gos.

26 Call for papers of the Center for Global Christianity and Mission of Boston University, 4 November 2019: 'The past and future of evangelical mission', https://www.bu.edu/ $\mathrm{cgcm} / 2019 / 11 / 04 /$ call-for-papers-the-past-and-future-of-evangelical-missions/. 
"a distraction."27 However, in many circles the Window seems to be alive and kicking. Although the Window is usually associated with American evangelicals, it also has appeal in a wide range of places, including Mexico, Brazil, South Korea, and African nations. ${ }^{28}$ According to Nami Kim, writing in 2018, "Despite some critical voices against them, both the Back to Jerusalem and the 10/40 Window are now popular mission themes and slogans, and have gained great momentum and followers among conservative Protestant Christians in South Korea and Korean immigrant churches in the United States as well."29 Indeed, there is evidence that indicates it has branched out ever since the 199os. It has done so in two distinct ways. Firstly, there is, admittedly scattered, evidence that the concept is used or at least habitually referred to in non-evangelical churches as well. Although the Window is associated with evangelicalism (and to a lesser extent Pentecostalism), it has been embraced by more denominations, ranging from Danish Lutherans and Baptists, to European Seventh Day Adventists and Dutch conservative Calvinists. ${ }^{30}$

Secondly, the 10/40 Window has now gained currency outside the US as well. In Europe, the map has gained less traction, and major missionary and Christian-humanitarian organizations like MAF and Tear do not refer to the 10/40 Window at all. However, there are some exceptions. The Dutch evangelical $3 \times \mathrm{XM}$ organization, for instance, sees the $10 / 40$ area as its primary focus. ${ }^{31}$ MissieNederland, the umbrella organization of Dutch evangelical missionary societies, referred to the Window in an October 2019 conference but also sees

27 Quoted by Kate Nutshell, "Why missions experts are redefining 'Unreached People Groups," Christianity Today (2019).

28 Mission Frontiers, January/February 2018 states that "We are not a Western-centric initiative. We are composed of house church movements from South Asia, Muslim background movements from the 10/40 window," 11. See also http://www.missionfrontiers.org/issue/ article/massive-prayer-and-missions-movements-of-the-9os, which refers to the massive prayer meetings in Africa and Seoul.

29 Nami Kim, "Carrying out the 'Great Commission'," in Colonialism and the Bible: contemporary reflections from the Global South, (eds.). Tat-siong Benny Liew and Fernando F. Segovia (London: Lexington Books, 2018), 159. On the Back to Jerusalem movement, see the movement's website at https://backtojerusalem.com/.

30 Evidence found in Jørgen Jørgensen, "Mission blandt muslimer drukner i mellemkirkeligt arbejde," Kristeligt Dagblad, 8 March 2004; Morten Filemon Olsen, "Guds mangfoldige kirke," 9 May 2018. https://baptist.dk/guds-mangfoldige-kirke/; website of the Dutch Seventh Day Adventists: https://www.adventist.nl/2011/12/10/; See also Abraham Guerrero, "Structure and mission effectiveness: a study focused on Seventh-day Adventist Mission to Unreached People Groups between 1980 and 2010," Graduate Dissertation (Andrews University, 2013); "Zending vaak gericht op korte termijn," Reformatorisch Dagblad, 9 May 2008. 
it as an increasingly outdated concept. ${ }^{32}$ The term also sporadically circulates in Denmark, France, Switzerland and Germany among some denominations. ${ }^{33}$ In the Global South, however, the map is popular among Pentecostals and evangelicals. Language restrictions hampered research in this area, but we have been able to track the 10/40 concept in Spanish-, Portuguese-, French-, German-, and English-speaking countries (including India), but not within the Middle East. Some evidence is provided by Fatiha Kaouès, who suggests that the 10/40 Window was introduced in Lebanon and used only by American missionaries. ${ }^{34}$ The concept is much more widespread in Latin America, as evidenced by, for instance, transnational evangelical organizations like Misiones Transculturales and Comibam (Cooperación Misionera Iberoamericana) that cater mostly to Latin America and US Hispanics. ${ }^{35}$ The independent Pentecostal David Israel Church in Lima, Peru, supports the 10/40 Window and has liaised with Pastor Shoukat Ashiq of the United Christian Gospel Church Prayer Ministry in Lahore to discuss mission in Pakistan. ${ }^{36}$ In Asia as well, indeed within the Window itself, the concept has gained recognition among evangelicals, including in South Korea, China (discussed above) and in India. ${ }^{37}$ An example is Gospel for Asia, based in Texas but founded by the South Indian K.P. Yohannan, who is affiliated with the indigenous evangelical/

32 Annemiek van den Berg, blog for Missie Nederland, 28 June 2019. https://www.missien ederland.nl/actueel/blog/artikel/2018/o6/19/Hoe-kunnen-ze-in-Hem-geloven-als-ze-niet -over-Hem-hebben-gehoord; Eunice Hoekman-van Stuijvenberg, "Nog zeker 3 miljard mensen niet bereikt met evangelie," Reformatorisch Dagblad, 5 October 2019.

33 "Missionare fürs „10/40-Fenster" gesucht,” website of Damit Menschen Gott begegnen: https://www.dmgint.de/mission/stichwort-berufung.html; website of German missionary society Wiedenest: https://www.wiedenest.de/; website of Club Lecture de Chretienne: https://www.clubdelecturechretienne.com/la-fenetre-10-40; Rebekka Schmidt, "Gebete für das 10/40-Fenster: «Jetzt beginnt der Aufbruch »", 5 June 2019.

34 Fatiha Kaouès, "Prosélytismes et évangélisation au Liban: un phénomène pluriel et mouvent," in Prosélytismes: Les nouvelles avant-gardes religieuses (eds.). Fatiha Kaouès and Myriam Laakili (Paris: CNSR Editions, 2016), 101.

35 “Qué Es La Ventana 10/40," 27 October 2009, website of Misiones Transculturales. http:// misionestransculturales.org/que-es-la-ventana-1040/; "Introducción a la Ventana 10/40," website of Comibam Internacional. https://www.comibam.org/es/introduccion-a-la-ven tana-1040-ppt/. The latter is co-founded by Luis Bush. Cf. Mision Posible, an Argentinabased organization that refers to unreached people groups. https://misionposible.org/ 1ooetnias/.

36 Website of David Israel Ministries: https://davidisrael-profeta.wixsite.com/peru; Website of United Christian Gospel Prayer Church Ministry: http://ucpgcm.org/about.html. The UCPGCM itself does not refer to the 10/40 Window; https://www.youtube.com/ watch?v=DpuM4e8Bl_I.

37 For India, see Pradip Thomas, Strong religion, zealous media: christian fundamentalism and communication in India (Los Angeles: Sage Publishing, 2008), 143, who sees the 
Pentecostal Believers Eastern Church, based in Kerala (south-west India) with a 3.5-million following mainly in India, Nepal, Myanmar, China, and Laos. ${ }^{38}$ The 10/40 Window is also used by the Saint Thomas Evangelical Church in India, an independent branch of the Indian Syriac church. Intriguingly, the parish in Kuwait, consisting of Indian expats, is actively supporting the 10/40 Window concept to promote mission in northern India. ${ }^{39}$ The success of the concept within the Indian evangelical movement is also evidenced by critique of the well-known puritan, Bangalore-based Bible teacher Zac Poonen: "if the Americans speak about the '10/40 Window', then the Indian preachers faithfully repeat the '10/40 Window'." 40 In short, unlike most literature suggests, there is evidence that the 10/40 Window is no longer an exclusively American concept, but has been appropriated by a multitude of non-American missionary societies all the way into the 2010 .

In this section, the 10/40 Window area will be analyzed as meta-geography. The term was coined by historian Kären Wigen and geographer Martin Lewis in their seminal The myth of continents: a critique of metageography. ${ }^{41}$ Wigen and Lewis defined meta-geography as "the set of spatial structures through which people order their knowledge of the world."42 Well-known examples are the East/West and North/South dichotomies. Less obvious are what they describe as "the myth of continents": common heuristic categories such as 'African fauna' make little sense from a biological point of view but have nevertheless functioned as container terms that appear to have credence. These kinds of constructed spatial frameworks impose an imaginary order that

Window map as mainly American. Cf. Chad M. Bauman, Pentecostals, proselytization, and anti-Christian violence in contemporary India (Oxford: Oxford University Press, 2015).

38 Website of Gospel for Asia: https://www.gfa.org/about/kpyohannan/; On the relationship between the 10/40 Window, US missionaries, and Yohannah, see Nicole Karapanagiot, "(Inadvertently) instructing missionaries in (public university) world religions courses: examining a pedagogical dilemma, its dimensions, and a course section solution," Teaching Theology \& Religion 20/1 (2017), 55 .

39 Website of St Thomas Evangelical Church in India Kuwait Parish: http://www.stecikuwait .org/hbm_new.asp.

40 Zac Poonen, A spiritual leader (Bangalore: CFC India, 1999), chapter 2, complains that Indian Christian preachers uncritically adopt the American concept of 10/40 Window.

41 Kären Wigen and Martin Lewis, The myth of continents: a critique of metageography (Berkeley/Los Angeles/London: UC Press, 1997).

42 Wigen and Lewis, The myth of continents, 9. 
acquires explanatory or persuasive power once imbued with social assent, even if they are out of tune with the actual physical or social world. ${ }^{43}$ For instance, the term 'Global South' is often used to denote regions that are actually predominantly in the northern hemisphere: Asia is completely north of the equator, Africa mostly so, Latin America is not, but Australia, which is in fact in the southern hemisphere is not part of the Global South. ${ }^{44}$ One conclusion drawn by Wigen and Lewis is particularly relevant for the argument developed in this article, namely that spatial meta-structures tend to cluster and isolate cultures, rather than show connectedness. These isolated spaces are imbued with cultural meaning, specific identities or even geographical determinism. ${ }^{45}$ One meta-geography for which this is obvious is Asia, a continent usually associated with exoticism and the absence of change or choice, unlike Europe in which action and diversity are considered more common.

Wigen and Lewis's observations seem particularly apt for the 10/40 Window, which until now has not been studied as meta-geography. We argue that the 10/40 Window is a meta-geographical designation through which missionary societies "order their knowledge of the world."46 This 10/40 geographical meta-structure intersects with existing discourses on the space the Window encapsulates, namely North Africa, the Middle East, and the entire southern part of Asia, areas that in Western thought are traditionally associated with cultural backwardness and stagnation. The 10/40 Window borrows from this Orientalism but, in turn, also reinforces it. In the view of Melani McAlister, the Window map therefore reflects "missionary opportunity" but really was a "signifier of the enslaved unreached peoples of the world." ${ }^{\text {77 }}$ More specifically, the map interconnects with other geographical meta-structures that have been current. ${ }^{48}$ Researchers have noted the congruence of the 10/40 Window map with Samuel Huntington's Clash of civilizations. ${ }^{49}$ As Huntington launched

43 Wigen and Lewis, The myth of continents, introduction.

44 See for instance Liew and Segovia, Colonialism and the Bible and Philip Jenkins, The new faces of Christianity: believing the Bible in the Global South (Oxford: Oxford University Press, 2006).

45 Wigen and Lewis, The myth of continents, 129-131.

46 Cf. Wigen and Lewis, The myth of continents, 9.

47 Melani McAlister, "The persecuted body: Evangelical internationalism, Islam, and the politics of fear," in Facing fear: the history of an emotion in global perspective, (eds.). Michael Laffan (Princeton: Princeton University Press, 2012), 144-145.

48 The map is also fairly similar to the World Map of Open Doors, ranking the 50 countries in the world in which Christians are most persecuted. https://opendoors.gopublic.nl/ webshop/ranglijst-christenvervolging-2018-a4.

49 Samuel Huntington, The clash of civilizations and the remaking of world order (New York: Touchstone, 1996). 


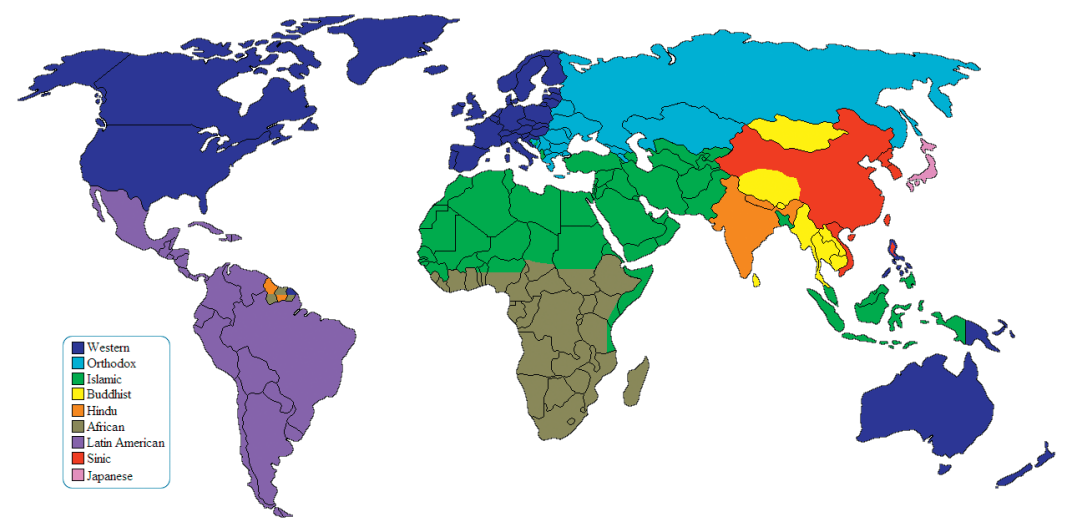

FIGURE 2 Huntington's map of the Clash of Civilizations

SOURCE HTTPS://NL.M.WIKIPEDIA.ORG/WIKI/BESTAND:CLASH_OF_ CIVILIZATIONS_MAP.PNG. IN PUBLIC DOMAIN

his thesis and accompanying map in 1992, the 10/40 Window thus predates Huntington's meta-geography [see Figure 2]. However, the parallels are obvious, in that the 10/40 Window overlaps fairly precisely with the green, orange, yellow, and red fields on the Huntington map. On one level this is hardly surprising, since Huntington's is really a standard map of world religions, but the very notion of thinking of transnational religions as civilizational areas in itself is part of a specific tradition that began with Oswald Spengler and Arnold Toynbee and has gained renewed traction in the post-1989 world..$^{50}$ Lewis and Wigen refer to the process of "geopolitical reimagination" in the 199os, after the end of the Cold War, of which Huntington, but obviously also Luis Bush, was an exponent. ${ }^{51}$ Like the Window makers, Huntington was intrigued in particular by the border between Christendom and Islam, and the parallel between the Huntington map and the Window map is striking in this respect. Huntington's notion of the "Bloody borders of Islam" 52 matches the 4oth parallel of the Window map, cutting precisely through the area in Europe in which the traditional frontiers were situated (the Iberian peninsula and the Balkans), and the 1oth parallel likewise through Africa (indeed it cuts precisely through the border of what is now Sudan and South Sudan). ${ }^{53}$ The 1oth parallel in this context is also conceptualized as a frontier between Christendom and Islam

$5^{\circ} \quad$ Wigen and Lewis, The myth of continents, chapter 5 .

51 Wigen and Lewis, The myth of continents, 134 .

52 Huntington, The clash of civilizations, chapter 3.

53 Cf. McAlister, 'Evangelical internationalism', 158. 
by the American investigative journalist Eliza Griswold and has thus gained some currency outside the missionary world. Although Griswold is critical of the concept of the 10/40 Window, the title of her book oddly confirms its metageographical logic. 54

In this context, the 10/40 Window meta-geography obviously resonates with current geopolitical concerns. Judy Han perceptively observed a congruence between the 10/40 Window map and Thomas Barnett's geo-strategical The Pentagon's new map (2004), which outlined the "Non-Integrating Gap," regions in the world that remained immune from "globalization's expanding web of connectivity." ${ }^{\prime 5}$ Political scientist Lee Marsden saw a connection between the US evangelicals' perceptions of the Middle East and US foreign policy vis-à-vis Iraq and Afghanistan in the early 20oos. ${ }^{56}$ Nadège Mézié, likewise, noted the interest "des organisations évangéliques pour une zone relevant de la géographie obsessionnelle de la politique étrangère américaine. ${ }^{.57}$ But caution is warranted. Melani MacAlister's plausible claim that the 10/40 Window "facilitated the increasingly hostile attitudes towards Islam" is not backed up by evidence. ${ }^{58}$ Likewise, the suggestion of Salah Guemriche that the American 10/40 missionaries that entered the Middle East after the Wars in Iraq constitute an evangelical Trojan Horse is suggestive rather than evidence-based, because the organization he refers to makes no mention whatsoever of American foreign policy, nor does it single out the Islamic world. ${ }^{59}$ Whereas the rhetoric of American foreign policy obviously resonates with the (American) 10/40 Window language, there is little empirical evidence of any convergence. Moreover, the 10/40 Window preceded the wave of US-anti-Islamism associated with $9 / 11$. More importantly, the wide success of the 10/40 concept outside the US and criticism of anti-Islamism by missionaries who support the 10/40 serve to nuance easy correlations. This is the argument of a thoughtful article

54 Eliza Griswold, The tenth parallel: Dispatches from the fault line between Christianity and Islam (New York: MacMillan, 2010).

55 Thomas Barnett, The Pentagon's new map. War and peace in the 21st century (New York: G.P. Putnam's Sons, 2004); Han, "Reaching the Unreached".

56 Marsden, "Conservative evangelicals," 120-122. On the geopolitical dimension of the map, see also Ashley James Barker, "Enfleshing hope: toward a Christian response to the rise of urban slum and squatter neighbourhoods," (PhD thesis, University of Melbourne, 2011), 65 .

57 Nadège Mézié, "Les évangéliques cartographient le monde. Le spiritual mapping," Archives de sciences sociales des religions 142 (2008), 63-85.

58 McAlister, The Kingdom of God has no borders. The same can be said for Salah Guemriche, Le Christ s'est arrêté à Tizi-Ouzou: Enquête sur les conversions en terre des islam (Paris: Éditions Denoël, 2010).

Website of win: https://www.win1040.org/. 
by Carolyn Gallaher, who shows that the evangelical Islam-bashing rhetoric of the likes of Jerry Falwell and Franklin Graham has been too easily extrapolated to US American evangelicalism generally. Indeed, her research shows that American evangelical missionary societies that operate in the Middle East are moving away from the political right and tend to see anti-Islamic rhetoric as a barrier to effective evangelism in the Middle East. Although Gallaher does not refer to the 10/40 Window as such, she cites societies such as Frontiers and Cross Global Link that embrace the concept. Her conclusion is that a nuanced review of evangelical geopolitical views is in order. ${ }^{60}$ In another context the Window may have geopolitical ramifications as well. The Diplomat, an authoritative news magazine on the Asia-Pacific region, published an article in 2018 by journalist Jeremy Luedi, suggestively stating that "This zone effectively overlaps with the scope of the BRI."61 This is only partly true. The BRI, the Belt and Road Initiative, is an economic masterplan by the Chinese government to channel major investments in what used to be the Silk Road zone but has now expanded to a worldwide enterprise. ${ }^{62}$

The 10/40 concept, once it is conceived as social reality, in turn generates or encompasses new meta-geographies, such as the $40 / 70$ and the $4 / 14$ Window. ${ }^{63}$ One of those is the meta-geography developed by the Back to Jerusalem movement, engendered within the Chinese Pentecostal churches in the 1920s. It is a reverse mission movement, aiming to convert the Islamic Middle East and Hindu India from China, all the way to Jerusalem, and thus mirroring the centrifugal forces of the historical Christian movement. Asian Christians have noted this geographical congruence between the two metageographies. According to Nami Kim, "The regions targeted by the Back to Jerusalem [movement] mostly overlap with the areas encompassed by the

6o Carolyn Gallaher, "Between Armageddon and hope: dispensational premillennialism and Evangelical missions in the Middle East," in Mapping the end times, (eds.). Dittmer and Sturm (Farnham, CRC Press, 2009), 209-232.

61 Jeremy Luedi, "China's Belt and Road: Exporting Evangelism?," The Diplomat (4 July 2018).

62 Cf. Tristan Sturm, "Religious movements,", in The Wiley Blackwell Companion to political geography, (eds.). John Agnew et al. (Malden: John Wiley \& Sons, 2015), 36o, on the 10/40 Window and mega-cities, and Clare Brickall, "Migration with a Mission: Geographies of Evangelical Mission(aries) to Post Communist Albania" (PhD thesis, London School of Economics, 2013), 52-53, on "how religious ideas can shape geopolitical imaginations, and consequently migratory destinations."

63 The 40/70 Window was conceived by Peter Wagner to designate the area in the world between 40 and 70 degrees latitude north (see below); the $4 / 14$ Window indicates the need to evangelize amongst children between 4 and 14 years old. The term was coined by World Vision and developed by Luis Bush. 
10/40 Window." ${ }^{64}$ Kim researched Korean missionary umbrella societies, such as the Unreached Peoples Mission Alliance, and found these to embrace both meta-geographical concepts. ${ }^{65}$ Another intriguing example is the Green Window concept, a spin-off from the 10/40 Window propagated by Brazilian missionaries who felt South America should be included. Green Window Ministries, established in 2012, targets the "unreached tribes" in the global "jenale verde," the global zone that spans the rainforests [F IGURE 3]. ${ }^{66}$ Although the focus of mission is on people, Green Window mission resonates with the current ascendancy of the ecological movement.

The meta-geography of the 10/40 Window has succeeded in generating mass support among evangelicals. In her recent study, Melani McAlister observed: "The 10/40 Window was appealing as a concept but also as a marketing tool." ${ }^{67}$ The way this has worked is partly through what Benedict Anderson in his seminal Imagined Communities has described as the "map-as-logo." The map is presented, devoid of any signifiers such as longitudes and latitudes, country names, etc., and becomes a simple logo. Thus "the map enters an infinitely reproducible series" and becomes visible on posters and mugs. Although it would be easy to trivialize low-culture and commercial expressions of metageography, in fact, Anderson argues, "the logo-map deeply penetrated into the popular imagination" and becomes a "powerful emblem." ${ }^{38}$ The map-as-logo no longer transmits geographical information but symbolizes a value or an ideology. The 10/40 Window map-as-logo, likewise, is devoid of any geographical information and text. ${ }^{69}$ There are now 10/40 Window T-shirts, games, cookbooks for kids, and even coffee blends that transmit the proposition that the Window equals mission itself. ${ }^{70}$ The widespread marketing products of

64 Kim, "Carrying out the 'Great Commission," 159. The connection is explicitly made by the Back to Jerusalem movement: https://backtojerusalem.com/about/\#.

65 Kim, "Carrying out the 'Great Commission'," 16o. Cf. Luedi, "China's Belt and Road: Exporting Evangelism".

66 Website of Green Window Ministries: http://www.greenwindowministries.org/uploads/ 3/4/9/3/34932967/aboutgw.pdf.

67 McAlister, The Kingdom of God has no borders, 144.

68 Benedict Anderson, Imagined communities: reflections on the origin and spread of nationalism (London/New York: Verso, 1983), chapter 10. He uses the example of the map of the British Empire in this section.

69 See for instance the logo of the UK-based Club 1040: https://clubio40.com.

70 For examples see Coffee for Missions: https://www.coffee4missions.com/buy-coffee-4 -missions/mission-roast-cold-brew-12-oz/; K.J. Larson et al. (eds.), Windowkids. Recipes of the 10/40 Window: A cookbook for kids: traditional recipes from Afghanistan to Yemen (Madison WI: InterVarsity Press, 2007). 


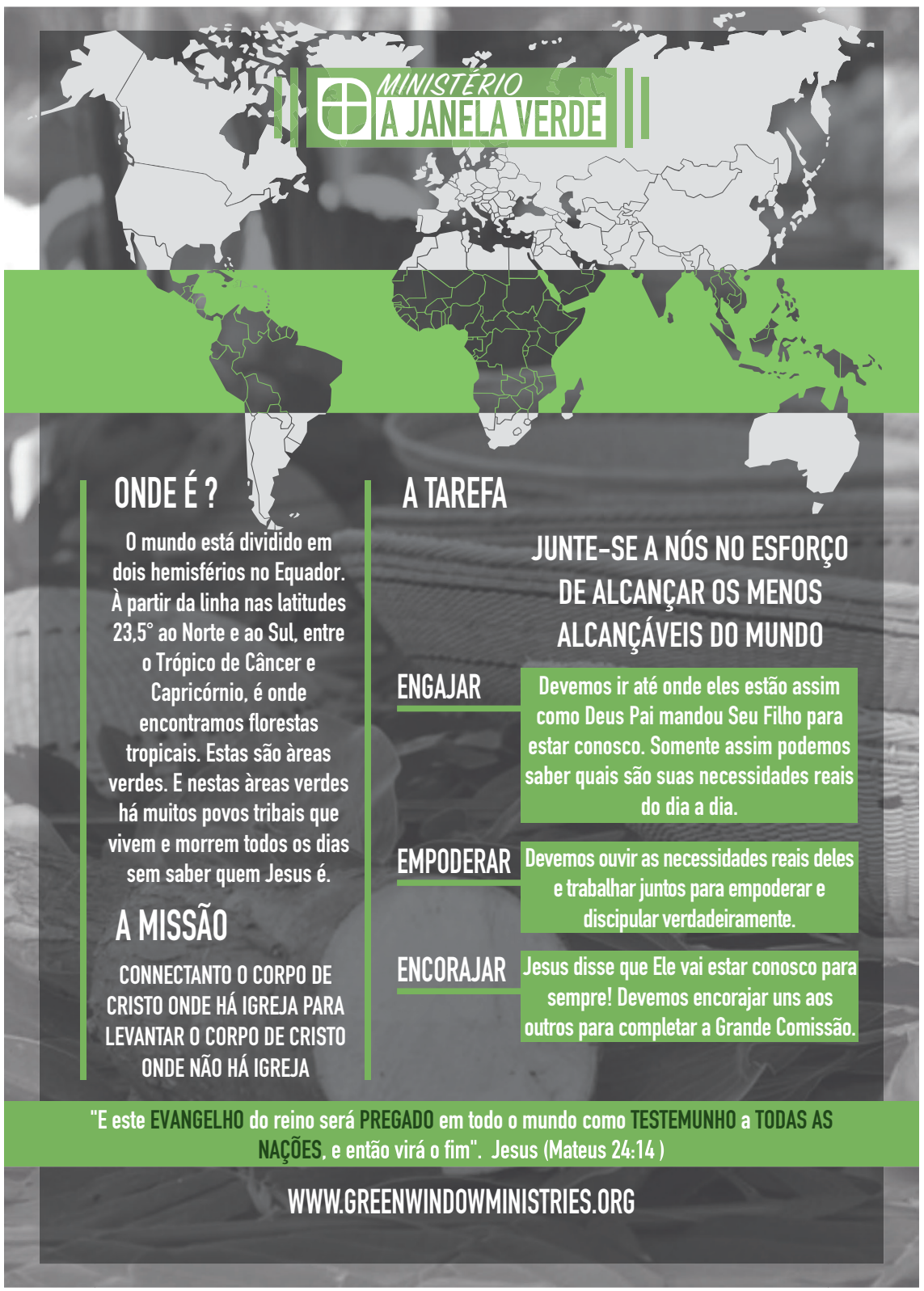

FIGURE 3 The Green Window SOURCE HTTP://WWW.GREENWINDOWMINISTRIES.ORG/. REPRODUCED WITH PERMISSION FROM GREEN WINDOW MINISTRIES 
the 10/40 Window map-as-logo show how the concept has become integral to evangelical mission.

\section{Critical Analysis of the 10/40 Window Map}

The 10/40 Window map-as-logo paradoxically reflects the power of the map whereas at the same time it voids the map of actual information because of its simplicity. As stated in the introduction, although researchers have reflected upon the concept of the Window and some of its features, until now the actual map has received surprisingly little attention. Indeed, missionary organizations seem not to reflect on the map at all and frequently simply reproduce the map, sometimes in sloppy versions. ${ }^{71}$ In this section we will study the map by employing several techniques offered by critical cartography. At first glance the 10/40 map is deceptively simple and straightforward, but these techniques help us to understand how the map is, in fact, a cluster of propositions and preconceptions about the world. Our aim is not so much to criticize the map, but rather to understand what it stands for and how cartography functions in the missionary movement. We will do so by analysing five distinct dimensions of the map through techniques which Piers Fotiadis has described as part of the "cartographer's cookbook": 1) projection; 2) selection; 3) use of colours; 4) symbols and 5) titles. ${ }^{72}$ We mainly use high-resolution maps generated by GMI (Global Mapping International), a former organization based in Colorado Springs, Colorado, an area that hosts a number of evangelical organizations. The majority of the official 10/40 Window maps were made by GMI in the 1990 and early 2000 s (also for Operation World) and seem to use exactly the same projection and format. ${ }^{73}$

71 See for instance the erroneous 10/40 Window map of Advancing Native Missions: https:// advancingnativemissions.com/what-is-the-10-40-window-and-why-is-it-important/.

72 The phrase was coined by Piers Fotiadis, "The strange power of maps. How maps work politically and influence our understanding of the world," School of Sociology, Politics, and International Studies (University of Bristol, Working Paper No. o6-og), 31. See also Christian Jacob, The sovereign map: theoretical approaches in cartography throughout history (Chicago: Chicago University Press, 2005), passim, and Jeremy Crampton, The power of maps in Introducing human geographies, (eds.). Cloke et al. (Abingdon: Routledge, 2014), 192-202.

73 The maps can be found at https://www.gmi.org/. Global Mapping International merged into the US Center for World Mission in 2006 and is now part of the newly set up Venture Mission in Pasadena. 
The first dimension is projection. The earth is a globe and a map is flat, which means that any projection is bound to distort. Cartographers make choices or, in the words of distinguished cartographer Arthur Robinson, choose "between a series of those kind of lesser-of-two-evils alternatives": either the map distorts or breaks up altogether. ${ }^{74}$ The most commonly used projection in the Western world was devised by Geert Cremer (Gerardus Mercator) in 1569. The projection was custom-made for nautical navigation and had the unique property that it exhibited perpendicular and straight parallels and meridians. The unfortunate side effect was that the regions furthest removed from the equator were inflated in size. Whereas Mercator's projection is still widely used, it was criticized both by cartographers such as Robinson ("It is of little use for purposes other than navigation") ${ }^{75}$ and ideologists, most notably the German historian Arno Peters. The latter denounced the Mercator projection for its cartographic imperialist character. By inflating the northern world and deflating Africa and the equatorial regions, the projection marginalized the importance of those regions. In 1967 Peters offered an alternative, so-called equal-size projection, which later came to be known as the Gall-Peters projection, and which restored Africa to its proper size and thus its rightful place in world history. The Peters projection does justice to size but distorts distance, and was in turn criticized by professional cartographers, but its ideological appeal was picked up by development organizations such as Oxfam, churches, and more recently by all public schools in the Boston area in an attempt to "decolonize the curriculum."76

Projection thus has implications, but so far, no analyst of the 10/40 Window has commented on its projection. The only scholar remarking on projection is Ju Hui Judy Han, however only in a half-sentence. She criticizes the 10/40 Window map for "invariably using the much-despised Mercator Projection."77 Han is factually wrong, for GMI used the Robinson projection. ${ }^{78}$ It was developed by Arthur Robinson, professor of Geography at the University of Wisconsin-Madison, in 1963 as a compromise between Mercator and equalsize projections, straddling size and distance. Robinson's projection tends to

74 Quoted in Myrna Oliver's obituary, "Arthur H. Robinson, 89; Cartographer hailed for map's elliptical design," Los Angeles Times (17 November 2004).

75 John Snyder, Flattening the Earth: two thousand years of map projections (Chicago: University of Chicago Press, 1993), 157.

76 The Independent, 2o March 2017.

77 Han, "Reaching the unreached," 186.

78 We are grateful for the advice of Dr Marco van Egmond, curator of maps at Utrecht University Library, Special Collections, on this matter. 
slightly distort polar regions but is fairly accurate towards the equator. The decision to use Robinson's projection is unsurprising. It had a rough start in the 1960s but became popular in the 1980s, for its elegant features and for being a workable compromise. ${ }^{79}$ In 1988 the US National Geographic Society adopted Robinson as the standard projection only to replace it in 1998 by the more accurate Winkel Tripel projection. Thus, at the time Luis Bush presented his plan, Robinson was the standard and fairly uncontroversial projection.

The second dimension is choice and selection. Every cartographer makes a choice of what areas are actually displayed on the map: what cities, rivers, or countries are depicted. Given the scarcity of space available, selection is necessary, but it is precisely in the selection that the cartographer decides "what to show and how to show it, and by extension, what not to show" - what Brian Harley described as "cartographic silence." ${ }^{80}$ According to Fotiadis, this selection tends to "reinforce the dominant discourse of the time" and "subtly alters our geopolitical perception of the area." ${ }^{81}$ In the case of the 10/40 Window map there are some noticeable pointers. The most obvious aspect of the map is that it focuses on and centralizes the Window. There are several world maps that highlight the Window in what becomes the right-hand, upper-centre part of the map, as can be seen in Figure 1. However, most maps centralize the Window, such as in Figure 4.

An obvious, easily overlooked aspect is what is called 'framed space,' the fact that the cartographer has decided to enclose a specific part of the world in a box, namely the frame of the illustration itself, which in turn is often determined by the shape and size of a page in a book. According to Christian Jacob, "The border thus plays a crucial role in the very definition of the representation that it delimits as a homogeneous space." ${ }^{22}$ Although some maps present the world map with the 10/40 Window in it, most cut off the map in the Atlantic, leaving the Americas out, creating a distinction between subject (US Christians) and the object (the Window area). For instance, Figure 4 displays a generic 10/40 Window map that seems fairly neutral. However, the first selection is obviously its focus; by removing the northern and southern parts of the globe, the Window area is centralized. Arthur Jay Klinghoffer, in his The power of projections: how maps reflect global politics and history, argues

79 Snyder, Flattening the Earth, 216.

8o Brian Harley, "Silences and secrecy: the hidden agenda of cartography in early modern Europe," Imago Mundi 40 (1988), 57-76.

81 Fotiadis, "The strange power of maps," 33.

82 Jacob, The sovereign map, 111. 
that the 10/40 maps that he has studied ensure that Asia and Africa are "very central visually because latitudes south of Cape Horn have been excised from the map's frame." ${ }^{83}$ There is also the matter of Harley's "cartographic silence": "we must read between the lines of the map [...] to discover the silences and contradictions that challenge the apparent honesty of the image." 84 Indeed, strictly speaking, the 10/40 Window maps do not show the 10/40 Window at all, since it is cut off in the West and the East. The map should include most of the United States and Mexico as well, but these areas obviously do not share the characteristics for which the Window area is known. Another striking feature is its focus on states: every state that has more than $50 \%$ landmass in the Window is part of the Window. The states in the Window are mentioned specifically, while those outside are not. On closer look, the odd one out is North Korea, which is located well within the Window but is not mentioned on this map. The reason is not obvious, for North Korea is clearly a potential target area for mission..$^{85}$ Conversely, Benin lies only partly within the Window but is nevertheless included. ${ }^{86}$

A further cartographic silence is even less obvious. Whereas mission is primarily concerned with people rather than with territory, the map shows states rather than humans. The legend explains that the Window consists of 57 countries as well as 3.6 billion people, but the map itself has a "dehumanizing character." This is true for most maps, as Sébastien Caquard and William Cartwright argue, but especially for conventional maps. ${ }^{87}$ One can imagine creative ways of tackling this, for instance in the map adopted by the Seventh Day Adventists, a 'humanized' version of the 10/40 Window map, devoid of state borders but with a photo of human faces. ${ }^{88}$ In recent years, the Window maps have been overtaken by the humanized UPG-cartograms that depict the map proportionally to the number of people living in a certain area. ${ }^{89}$ Although the Joshua Project still refers to the 10/40 Window in a more traditional Robinson

\footnotetext{
83 Klinghoffer, The power of projections, 132.

84 J.B. Harley, "Deconstructing the map," Cartographica 26/2 (1989), 1-20.

85 It may have been excluded because technically less than $50 \%$ is in the Window. However, it is included in the original list of states in the 10/40 Window, probably because it was felt it shared the characteristics of the area that are problematic.

86 We owe this observation to Martha Frederiks.

87 Sébastien Caquard and William Cartwright, "Narrative cartography: from mapping stories to the narrative of maps and mapping," The Cartographic Journal 51/2 (2014), 103.

88 Source: https://gm.adventistmission.org/the-1040-window.

89 https://joshuaproject.net/maps/cartograms.
} 


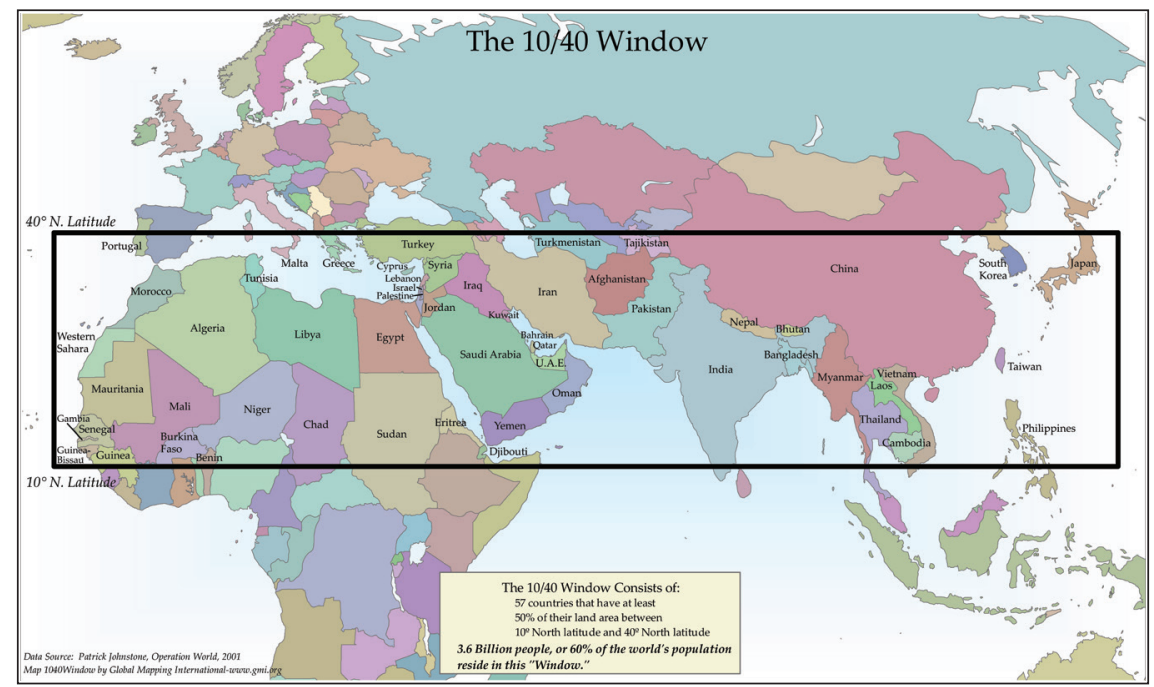

FIGURE 4 The 10/40 Window

SOURCE: HTTPS://WWW.MISSIONINFOBANK.ORG/. REPRODUCED WITH PERMISSION FROM MISSION INFO BANK

projection world map, it also produces such People Group Cartograms ${ }^{90}$ and world maps in which UPGs are no longer tied to fixed regions (for instance by taking into account migration), thus breaking the geographical determinism which marred some of the traditional 10/40 Window maps. ${ }^{91}$ The Travelling Team, for instance, published statistics and an accompanying map that show that $62 \%$ of international students in the USA are from the $10 / 40$ Window. ${ }^{92}$ Another way to humanize the maps is through the technique of Cinemapping: the use of maps in films or documentaries, allowing for a cinematographic interplay between map, sound, and vision. ${ }^{93}$ The 10/40 Window movement has made effective use of this technique through the rise of YouTube in 2005. An example is "Introducing the 10/40 Window," a five-minute documentary in

90 See for instance https://joshuaproject.net/assets/media/maps/fpg-popl-by-region-car togram.pdf.

91 See for instance https://joshuaproject.net/assets/media/maps/frontier-indigenous-vs -diaspora.pdf.

92 The Travelling Team: "Mission stats": http://www.thetravelingteam.org/stats.

93 Cf. Sébastien Caquard and D.R. Fraser Taylor, "What is cinematic cartography?," The Cartographic Journal 46/1 (2014), 5-8. 
which human faces, as representatives of the Unreached People Groups, are depicted in front of the map. ${ }^{94}$

The third dimension of the map is related to colour. Stuart Hall argues that whereas "Colours do not have any 'true' or fixed meaning," cultures have a "conceptual colour system." ${ }^{95}$ The meaning and even categorization of colours are human constructs that depend on culture, thus the 10/40 Window map should be explained in terms of Western cultural coding. Colours have been analyzed in depth by French historian Michel Pastoureau in a groundbreaking series of monographs on red, green, yellow, and blue. ${ }^{96}$ Whereas blue, for instance, was vilified by the Ancient Greeks, in modern Western society it has overwhelmingly positive connotations. As Jean-Paul Bord explains, "Le bleu est en effet, la couleur preferee [...] dans tous les pays du monde occidental; [...] il est calme, pacifique, lointain, presque neutre." Red, however, is associated with danger, blood, or fire; yellow with light and energy. ${ }^{97}$ The colours also have more specific associations, such as red for communism and blue for the United Nations. On both levels, colours on maps can communicate geopolitical values (for instance by marking the Soviet Union as red on the map: menacing and Communist), but the coding is not necessarily obvious when one considers that both Ireland and Saudi Arabia can be associated with green for very different reasons. ${ }^{98}$ Colouring the map has an additional attribute that has the propensity of altering the perception of the social world, namely that it suggests homogeneity. For instance, by giving each state a specific colour, as many world maps do, they inadvertently confirm the Westphalian system, overestimate the importance of state borders, and suggest national, cultural and social cohesion. ${ }^{99}$

94 Advancing Native Missions, "Introduction to the 10/40 Window": https://www.youtube .com/watch? $\mathrm{v}=\mathrm{V}_{4}$ CgsSy3uxg\& $\mathrm{t}=1 \mathrm{~s}$.

95 Stuart Hall, "The work of representation," in Representation: cultural representations and signifying practices, (eds.). Idem (London: Open University, 1997), 26.

96 Michel Pastoureau, Red: the history of a color (Princeton: Princeton University Press, 2016); Green: the history of a color (Princeton: Princeton University Press, 2014); Black: the history of a color (Princeton, Princeton University Press, 2008); Blue: the history of a color (Princeton: Princeton University Press, 2001); Yellow: the history of a color (Princeton: Princeton University Press, 2019).

97 Jean Paul Bord, "Cartographie, géographie et propagande. De quelques cas dans l'Europe de l'après-guerre," Vingtième Siècle. Revue d'histoire 8o (special issue on 'Propagande et communication politique dans les démocraties européennes (1945-2003)') (2003), 15-24; cf. Mézié, "Les évangéliques cartographient le monde," 81.

98 Cf. Fotiades, "The strange power of maps," 34.

99 Fotiades, "The strange power of maps," 34. 
The various versions of the 10/40 Window map have no fixed colour schemes. Indeed, on the map presented in Figure 4, for instance, the colour pattern seems fairly random, possibly even computer-generated. However, the patterns may not be completely arbitrary. China has a distinct red colour for Communism, whereas the majority of Muslim countries in the Maghreb and the Middle East have shades of green (Morocco, Algeria, Tunisia, Libya, Turkey, Syria, Saudi Arabia, the United Arabic Emirates, Turkmenistan, and Pakistan), which resonates with green as the colour of Islam. The problem with such an interpretation is that in a fair number of cases the comparison does not hold: France, Russia, and Finland are also green, whereas Afghanistan and Egypt are red. However, these countries are outside the Window, where other cartographic rules seem to apply (for instance: countries outside the Window are not named). Within the Window the world of Islam is dominated by tints of green, and Communism by red or brown (North Korea). Moreover, India, which could be uniquely associated with Hinduism, has a distinct colour grey, which is not visible anywhere else on the map.

This also shows in Figure 5, another map by GMI depicting "the dominant religious blocks." Here colour patterns are obviously deliberate: green for Islam, yellow for Hinduism, orange for Buddhism (the colour of Buddhist monks' robes) and brown for non-religious. On this map the colouring has overwhelming consequences. For one, even if the legend refers to a religious 'majority' in the areas marked on the map, as a result of the homogenous colouring of those areas any indication of religious diversity is erased. This impression is strengthened by the title of the map, referring to religious 'blocks,' which can be associated with the perceived impermeability of these regions. Since all the countries outside the Window do not seem to conform to any colour coding, the impression is given that within the Window religion is dominated by blocks, whereas outside the Window religious plurality reigns. There is, of course, also the matter of how the underlying statistics are employed. Does it make sense to cluster South Korea and China together as "non-religious" and refer to Japan as mainly Buddhist (whereas the largest religion rather is Shintoism)?100 Moreover, why are Taiwan, the Philippines, and Israel left out? Is it perhaps because their culture and religion or political affiliation are geared towards the West and are therefore not part of a "block"?

100 Technically, both China and South Korea have a non-religious majority, but there are also maps that refer to China as Confucian. In the case of Japan, the largest religion is actually Shintoism, followed by Buddhism. 




FIGURE 5 The dominant religious blocks within the 10/40 Window SOURCE: HTTPS://WWW.MISSIONINFOBANK.ORG/. REPRODUCED WITH PERMISSION FROM MISSION INFO BANK

The fourth dimension in critical cartography involves symbols and borders. The 10/40 Window map is mostly devoid of symbols, but the most powerful symbolism of the map is one that is easily overlooked because it is such a common feature in cartography: state borders. Earlier we noted that most 10/40 Window maps, as most Western maps indeed, validate the Westphalian state-system perspective by adding borders of states. The map thus is not 'a map' of the world, but by definition a political map. Since the Window is concerned with people groups and religions, this is not an obvious choice, but it is not easy to see what its function is either, other than to conform to standard practice and present a map that most Western viewers recognize. Its unfortunate side effect is discussed above in the section on colour-it perpetuates a Western political discourse and has a dehumanizing effect. A much more dominant element of the 10/40 map is, of course, the border of the Window itself, characterized by a dark, black, bold stroke. Just as with the state border line, which is continuous, it suggests that the Window is a tightly boxed-off space, just like a sovereign state-or even more so, considering the thickness of the line. It thus cuts off the 10/40 Window from the interconnected modern global world, or at least 
suggests great difficulty in accessing the Window. ${ }^{101}$ It is strangely incongruent with the 'window' concept itself, which suggests transparency.102

The fifth and final dimension of the map we discuss is the text: title, language, and toponymy. Each of these communicates values. The title of Figure 5, for instance, "Dominant Religious Blocks," effectively pairs two negative connotations ("dominant" and "block"). Figure 6, likewise, shows the "prevelance" [sic] of Islam, showing the percentage of the Muslim population in countries within the Window. In itself "prevalence" seems a neutral word, but it has two significant, negative, connotations. Stemming from the Latin praevalere, it literally means "to be stronger, to master"; moreover, in the English language, its most common use is in connection with the spread of diseases.

The legend is also of importance here. Take, for instance, Figure 7 , a fairly generic 10/40 Window infograph of the Far East Broadcasting Company (FEBC), a US radio organization established in 1945 and focusing on proclaiming the Gospel in Asia. ${ }^{103}$ The data was derived from the Joshua Project. The legend includes several factual statements connected to the Window, such as: $90 \%$ of the poorest countries are in the Window, 45 of the 50 most persecuted countries are in the Window, the Window is dominated by three religious blocks. This information is in line with what most missionary societies claim about the Window. The specific information in this infograph has credibility because of the countless intertextual links: the fact that numerous missionary societies perpetuate the same figures lends weight to the reliability of the narrative. At first sight it seems as if this information is factually correct-the viewer would have no reason nor means to check its veracity. The point here is, however, in the framing. As Jeremy Crampton argues, "The map has a narrative. This does not mean the data are wrong or poorly chosen. We can still frame the argument when the data are bang up to date." 104 The juxtaposition of these factual statements on a single sheet in connection with the map suggests a causal relationship that may not be there. As Crampton argues, it is conceivable that the causal link is rather because of "spatial externalities"; as such, the map shows things, but also "silences," elements that may be of importance. ${ }^{105}$ Or, in this case: is the poverty in the 10/40 Window causally connected to the Window

\footnotetext{
101 Cf. Fotiadis, "The strange power of maps," 24.

102 The area of the Window is frequently nicknamed "The Resistant Belt," which imparts a very different image. E.g. https://joshuaproject.net/resources/articles/10_4O_window.

103 Far East Broadcasting Company, "The 10/40 Window: a visual". https://www.febc.org/ 10-40-window-infograph.

104 Crampton, "The power of maps," 193.

105 Crampton, "The power of maps," 194.
} 


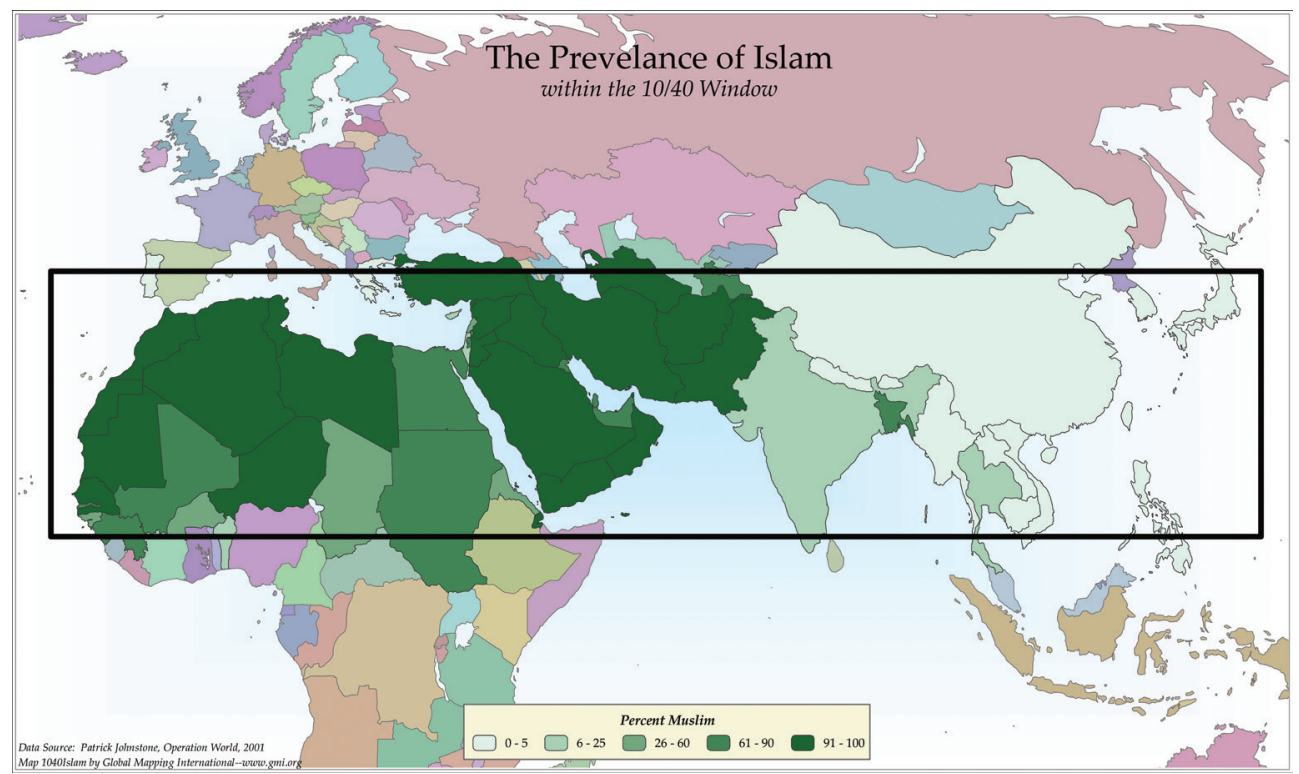

FIGURE 6 SOURCE: HTTPS://WWW.MISSIONINFOBANK.ORG/. REPRODUCED WITH PERMISSION FROM MISSION INFO BANK

itself and its conditions, or the result of external causes (for instance, economic exploitation of rich Western countries)? Of course, the map does not deny such a causal link at all, but the cartographic narrative, by its very framing of the Window, is geared towards 'local' explanations.

In many 10/40 Window maps the toponymy is minimal, but in Figure 4 the names of states are mentioned. The power of discourse is often exerted in the obvious, or in this case, the fact that the language is English. This is only what one would expect, the map being produced by an American company for a largely US audience. However, surprisingly, the vast majority of 10/40 Window maps in non-English-speaking countries still use English text. Take, for instance, the Spanish-speaking world, in which "Ventana 10/40" is the term used, but in which maps seem to be in English only. ${ }^{106}$ However, according to Christian Jacob in his seminal The sovereign map, the "language that names all the places of the world is symbolically appropriating them."107 The linguistic imperialism

106 See for instance http://misionestransculturales.org/que-es-la-ventana-1040/. It uses English maps but occasionally adds Spanish titles.

107 Jacob, The sovereign map, 212; Alastair Pennycook, The cultural politics of English as an international language (London/New York: Routledge, 1994). 




FIGURE 7 SOURCE: HTTPS://WWW.FEBC.ORG/10-40-WINDOW-INFOGRAPH. REPRODUCED WITH PERMISSION FROM FAR EAST BROADCASTING COMPANY

of the 10/40 Window map may be one of the most influential strategies of territoriality. In this case as well, it is a common attribute of most world maps and not specifically tied to the $10 / 40$ Window map. Moreover, the reason is probably pragmatic: existing maps are easier to reproduce, and the practice may not amount to anything more than a careless attitude towards cartographic material that is common with many organizations. However, it is incongruous 
with the purported ambition of the 10/40 Window map, which is to represent the People Groups of world Christianity in their linguistic diversity.

\section{$5 \quad$ Discourse on UPGs and Spiritual Warfare}

The final section builds on the meta-geographical and critical cartographical insights acquired in sections 3 and 4 by investigating the cartographic discourse that is integral to the $10 / 40$ Window concept. This can pertain to specific phrases derived from cartography (e.g. "wiping something off the map"), but more generally with spatial language. This section focuses on two spatial discourses integral to the 10/40 Window, centering around the two core concepts of "unreached people groups" and "spiritual warfare."

The first, the concept of "unreached people groups" (UPGs) was originally conceived by Ralph Winter in the 1970s. Despite sustained criticism, even from within missiologist circles, ${ }^{108}$ the original UPG-concept is still intact. Its appeal may be explained from the fact that it resonates with the biblical 'peoples' or 'nations' of the world. The focus here, however, is not on this particular concept, but on how it relates to geographical metaphors, in particular the notion of 'reaching.' In a 2018 schematic overview published by the Joshua Project [Figure 8] binary language is use to divide the world population into two major groups: "reached" and "unreached." 109 Reached groups are divided into "followers of Jesus," "other nominal Christians," and "culturally-near non-believers." The 'nearness' of the latter is decided, not primarily by geographical but by social distance, by being part of a People Group in which Christians are active. The "unreached" are "culturally-distant non-believers," who live in People Groups in which few or no Christians are active. The 10/40 Window is not specifically mentioned here but overlaps neatly with the "culturally-distant nonbelievers" plus the "culturally near non-believers" in China. The purpose of this model is to make a "mobilization challenge" to send more missionaries to the Window. ${ }^{110}$ Since cultural distance is defined by people groups, that in turn are connected to meta-geographical spaces, such as "Pacific" and "non-Muslim Africa", the spatial designations are in effect geographical in nature and confirm the basic logic of the 10/40 Window.

\footnotetext{
108 Lee and Park, "Beyond people group thinking".

109 Original in Rebecca Lewis, "Clarifying the remaining frontier mission task," International Journal of Frontier Missiology 35/4 (2018), 159.

110 https://joshuaproject.net/assets/media/handouts/clarifying-the-remaining-task.pdf.
} 


\section{Clarifying the Remaining Mission Task}

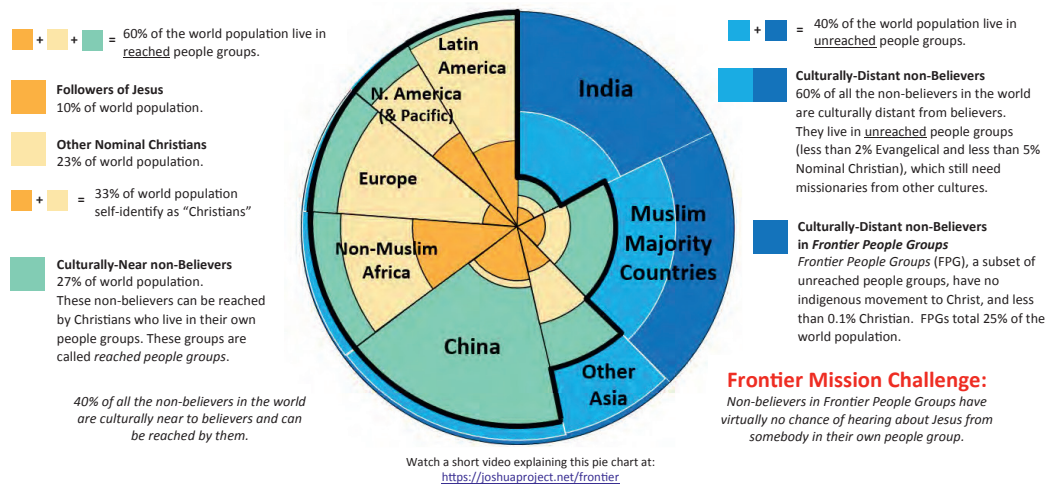

Mobilization Challenge: For every 30 missionaries that go to the reached $\square$ people groups of the world ... roughly ONE missionary goes to the unreached

\section{0 to 1}

\begin{tabular}{|r|c|c|}
\hline Perspective & Non-Frontier People Groups & $\begin{array}{c}\text { Frontier People Groups } \\
\text { (the neediest subset of Unreached People Groups) }\end{array}$ \\
\hline Where Christians live & 9,999 out of $10,000(99.99 \%)$ & 1 out of $10,000(0.01 \%)$ \\
\hline Christians to non-Christians & 4,000 Christians for every 10,000 non-Christians & 1 Christian for every 10,000 non-Christians \\
\hline Where cross-cultural missionaries serve & Greater than $99 \%$ & Less than $1 \%$ \\
\hline Cross-cultural missionaries to non-Christians & 1 worker for every 8,500 non-Christians & 1 worker for every $7,000,000$ non-Christians \\
\hline
\end{tabular}

Sources: Joshua Project, Operation World, UFM 35:4 Winter 2018

FIGURE 8 The Joshua Project's schematic representation by the world's reached and unreached people groups SOURCE: HTTPS://JOSHUAPROJECT.NET/ASSETS/MEDIA/HANDOUTS/ CLARIFYING-THE-REMAINING-TASK.PDF. INFOGRAPH CREATED BY REBECCA LEWIS, HTTPS://WWW.IJFM.ORG/PDFS_IJFM/35_4_PDFS/ IJFM_35_4-LEWIS.PDF. REPRODUCED WITH PERMISSION FROM THE JOSHUA PROJECT AND LEWIS

The language of reached and unreached includes another spatial signifier, namely "boundary" or "frontier." Unlike on the original Window maps, the Joshua Project more recently has downgraded the significance of political boundaries by classifying People Groups Across Countries (PGAC). ${ }^{111}$ The term frontier, however, has a very different connotation. According to the Joshua Project, a "Frontier People Group" (FPG) is one that has no self-sustaining Gospel movement and very few Christians. As Figure 9 shows, the vast majority (90\%) of FPGs are situated smack inside the 10/40 Window. ${ }^{112}$ According to

111 Joshua Project website: https://joshuaproject.net/resources/articles/how_many_people_ groups_are_there.

112 Joshua Project website: https://joshuaproject.net/assets/media/handouts/frontier-peo ples-overview.pdf. Original in Lewis, "Clarifying the remaining frontier mission task," 167. 


\section{Frontier People Groups}

\section{WHO are they?}

Frontier people groups are a subset of unreached people groups that have $0.1 \%$ or fewer who identify with Jesus in any way. These are the "most unreached of the unreached."

\section{1 or fewer per 1,000}

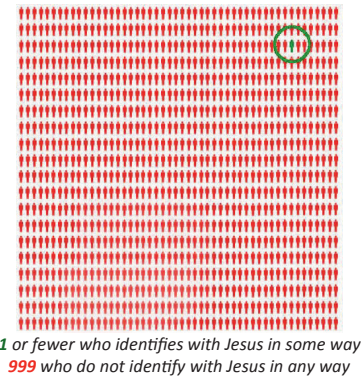

\section{WHERE are they?}

Of the 5,032 Frontier people groups, 4,570 are in the 10/40 Window. $90 \%$ of Frontier peoples live between 10 and 40 degrees north latitude stretching across North Africa, Middle East, Central and East Asia.

\section{9 out of 10 are in the $10 / 40$ Window}

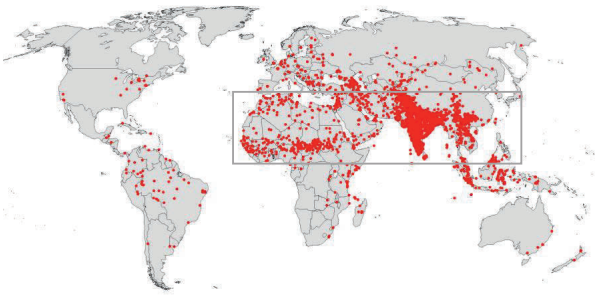

\section{WHY are they strategic?}

1.88 billion souls live in Frontier unreached people groups.

Of everyone alive today, $25 \%$ live in a people group where there is almost no opportunity to hear about Jesus.

1 in 4



More people live in Frontier people groups than in North America, Central America, South America, Europe and Australia-combined!

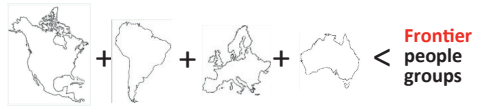

\section{WHERE are missionaries going?}

$96 \%$ go to the $60 \%$ of world population where more than $5 \%$ identify with Jesus. $3 \%$ go to the $15 \%$ of world population where $0.1 \%$ to $5 \%$ identify with Jesus. $1 \%$ goes to the $25 \%$ of world population where less than $0.1 \%$ identify with Jesus.

\section{Only 1 in 100 missionaries}



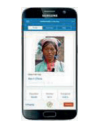

Mobile App



\section{HOW can you be involved?}

Pray for and share vision for Frontier peoples. joshuaproject.net/frontier

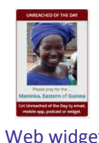

Web widget

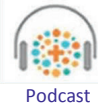

Figure 9 The Joshua Project's overview of Frontier People Groups in the 10/40 Window SOURCE: HTTPS://JOSHUAPROJECT.NET/ASSETS/MEDIA/HANDOUTS/ FRONTIER-PEOPLES-OVERVIEW.PDF. MAP CREATED BY REBECCA LEWIS, HTTPS://WWW.IJFM.ORG/PDFS_IJFM/35_4_PDFS/IJFM_35_4-LEWIS.PDF. REPRODUCED WITH PERMISSION FROM THE JOSHUA PROJECT AND LEWIS 
Mission Frontiers, "The concept of Frontier People Groups is still developing."113 Robby Butler, Director of Mission Network and one-time assistant of Ralph Winter, argues that "frontier" designates not so much a boundary in a political or military sense, but what the Merriam Webster dictionary defines as "a region that forms the margin of settled or developed territory"114 For Butler, such a region requires "pioneer work" in the orchard in bringing the Gospel. This language of frontiers and pioneers appeals to American supporters who associate these words with the 19th-century settlers in the American West. The Frontiers are not those of American civilization, though, but of the Kingdom of God, which is represented as a mission "field" that requires "seed."

Where the language of reached and unreached and of mission field is pacific, terms like frontier and kingdom open up a more martial repertoire. Criticism of a pacific understanding of mission was delivered by an associate of Luis Bush, Peter Wagner, for whom the Kingdom was not concerned with whether people were reached or unreached, but with spiritual warfare. ${ }^{115}$ The Kingdom encompassed geographical space, and had to be defended and extended. In this sense, the 10/40 Window map was not about a window for missionary opportunity; it was a military map with which to devise strategy. Wagner was a prolific and enterprising missiologist, an exponent of the revivalist movement who wrote extensively on spiritual warfare. In particular, his ideas tie in with the notion of "spiritual mapping," a term coined in 1990 by George Otis, a missiologist affiliated with the Lausanne Committee. ${ }^{116}$ Spiritual mapping facilitates spiritual warfare, or more specifically "Strategic-Level Spiritual Warfare" (sLSw) or "Cosmic-Level Spiritual Warfare" (CLSW). ${ }^{117}$ The conflation of territory with spiritual warfare was already existent in Luis Bush's original concept. To him, the 10/40 Window was not just a place of poverty and unreached territory; it housed "numerous strongholds of Satan."118 According to Otis, "spiritual strongholds are the invisible structures of thought and authority that are

113 Mission Frontiers website: https://www.missionfrontiers.org/issue/article/introducing -frontier-people-groups-fpgs.

114 https://www.merriam-webster.com/dictionary/frontier.

115 Erwin van der Meer, "The strategic level spiritual warfare theology of C. Peter Wagner and its implications for Christian mission in Malawi," PhD Thesis (University of South Africa, 2008).

116 On Peter Wagner and George Otis, see Rene Holvast, Spiritual mapping in the United States and Argentina, 1989-2005: a geography of fear (Leiden: Brill, 2008), 90-92.

117 Holvast, Spiritual mapping, 4.

118 Bush, "Reaching the core of the core". 
erected through the combined agency of demonic influence and human will."119 They are territorial in the sense that actual sites, such as mosques or Hindu temples are "not strongholds but portals to the Other Side."120 As the Dutch missiologist Rene Holvast explained, the strongholds "are usually defined along the lines of normal human geographical structures like cities, countries and provinces."121 And strongholds of the enemy, whether they be temples, cities, or kingdoms, must be torn down. ${ }^{122}$ "It is evident," Bush stated, "that the forces of Satan have great power and will resist all attempts to be overcome. If we are to storm the enemy's territory, we must put on the full armour of God and fight with the weapons of spiritual warfare described in Ephesians 6." ${ }^{\prime 23}$ Chuck Pierce, an associate of Wagner and chair of the Apostolic Reformed Global Spheres Inc. (GSI), concluded that it is important to understand "God's plan of territorial authority."124

To Bush, the 10/40 Window is not just any place on earth, for at its epicenter is located the original site of Eden, in which God offered dominion over the earth to Adam and Eve. ${ }^{125}$ It is, however, also the place where the Tower of Babel was built, and where the demonic Princes of Babylon and Persia reigned. In a dramatic imagery, Otis explained in 1991 that Satan himself had gained command of Iraq / Babylon, its rich oil reserves the very remnants of the once lush animal and plant life of the garden of Eden. ${ }^{126}$ According to Peter Wagner, such demonic forces are still in play. Wagner adopted the 10/40 Window as the geographical framework for the spiritual mapping movement. ${ }^{127} \mathrm{He}$ also believed that the demonic "Queen of Heaven" is ruling the "40/70 Window," a concept he coined to cover Europe and northern Asia as a territory of people who were blinded to true faith. ${ }^{128}$ In the wake of $9 / 11$ and the increased attention to the Middle East, however, the 40/70 Window failed to capture the imagination

\footnotetext{
119 George Otis, Strongholds of the 10/40 Window. Intercessor's guide to the world's least evangelized nations (Seattle: YWAM, 1995), foreword.

120 Otis, Strongholds of the 10/40 Window.

121 Holvast, Spiritual mapping, 5 .

122 Peter Wagner, Breaking strongholds in your city (Ventura: Regal Books, 1993); John Dawson, Taking our cities for God (Lake Mary FL: Charisma House, 1989).

123 Bush, "Reaching the core of the core".

124 Wagner, Breaking strongholds, 47.

125 Bush, "Reaching the core of the core", 452; Cf. Genesis 1: 26.

126 George Otis, The last of the giants: lifting the veil on Islam and the end times (Grand Rapids: Baker Book House Company, 1991), 99.

127 Holvast, Spiritual mapping, 99. For Wagner and the 10/40 Window, see Holvast, Spiritual mapping, chapter III.

128 Peter Wagner (ed.), The Queen's domain. Advancing God's kingdom in the 40/70 window (Colorado Springs: Wagner Publications, 20oo).
} 
of the US, but the 10/40 Window was successfully reconceptualized as a spiritual war zone. The most powerful weapon in spiritual warfare is prayer, and especially in the 1990 s the AD200o movement succeeded in mobilizing millions of Christians all over the world to pray for the 10/40 Window. According to Mission Frontiers, 1993 saw the "largest unified prayer effort in the history of the church," in which a reported 21 million Christians prayed for all nations in the 10/40 Window for an entire month. ${ }^{129}$ Although Melani MacAlister and Rene Holvast may be right in associating the spiritual language connected to the $10 / 40$ Window with "fear," it rather exudes triumphalism. ${ }^{130}$ Although the strongholds of Satan should be approached with dread, the entire spiritual military operation of the $\mathrm{AD} 2000$ movement was driven by the hope for a speedy victory, possibly by the millennium itself. The territorial interpretation of spiritual warfare was severely criticized by Western theologians and historians. Brian Stanley, for instance, argued that it can lead "Christians into forms of crass and implicitly racist territorialism, in which particular regions of the map are branded as being peculiarly subject to satanic dominion."131 Even so, it has gained traction with evangelicals and neo-Pentecostals, especially in non-Western regions. ${ }^{132}$

This article has set out to show that maps matter. The 10/40 Window map visualizes global missionary ambitions, but also creates new social realities that in turn reshape the goals missionary societies set themselves. Although the 10/40 Window has been discussed by both missionaries and academics, the actual map has been strangely overlooked. The article first showed how the 10/40 Window is still a robust concept in many circles and can, moreover, no longer be exclusively tied to American evangelicals, as it has impacted European and non-Western mission as well. Subsequently, this article analyzed the 10/40 Window map in three consecutive steps. The first step was to understand the Window as meta-geography, an imaginary space imbued with values such as poverty and spiritual darkness. The Window as meta-geography reinforces and

\footnotetext{
129 http://www.missionfrontiers.org/issue/article/massive-prayer-and-missions-movements -of-the-gos.

130 Probably more so. The title of Holvast's book includes the key word "fear," but in his actual study the word is never used in connection with spiritual mapping.

131 Holvast, Spiritual mapping, 2; Brian Stanley, "Conversion to Christianity: The colonization of the mind?," International Review of Mission 92 (2009), 328.

132 Holvast, Spiritual mapping, 2.
} 
reshapes older notions of Orientalism related to Asia and the Middle East, but also intersects with geopolitical concerns. The second step considered how cartographic choices impacted the visual 'propositions' of the 10/40 Window map. Although the projection steered clear of ideologized notions of global relations, the map articulated a typically Western state-oriented view of the world by homogenizing states and accentuating national borders. However, more recent infographs by the Joshua Project 'humanized' the otherwise 'sanitized' 10/40 Window maps and show the cartographic learning curve of the missionary movement. Maps used colour codings to create dichotomies between world religions, and between the plural West and homogenous nonChristian world religions, a dichotomy emphasized by the boxed framework of the Window on the map. The textual dimension of the map, titles and legends, accentuated these differences. The third step built on this by exploring the cartographic discourse of the map in two variants: language related to distance and reach, and language related to spiritual warfare. The overall argument was that the 10/40 Window map can be seen as a territorial strategy of the missionary movement, a visual way to lay claim on territory.

Two disclaimers are in order. First, there is reason to believe that many versions of the maps have been disseminated without paying conscious attention to the visual discourses the maps propagate. It is therefore difficult to measure whether some of the analyses pertain to a conscious missionary strategy, or indeed whether missionary societies are unaware of this. For instance, there is an odd disconnect between the missionary focus on "people groups" and the dehumanized nature of the map. Second, several features of the map, such as orientation, projection, state borders, and names of states are generic for most Western world maps. At the same time, however, these remarks do not undermine, indeed could even confirm, the fact that the 10/40 map, whether it be deliberately or unwittingly, continues a Western cartographic discourse. As Piers Fotiadis notes, "it is not necessarily the case that the actual author of the map is conscious of the potential political message of the map they create; rather, they may draw a map which is guided by the socially constructed dominant discourses of the time or of their institution."133

The point of this article was not so much to criticize the 10/40 map per se, since several of its features are endemic to most Western maps, but rather to point out the visual discourse of territoriality that the 10/40 Window map propagates, whether it be conscious or not. This research builds on the application of the 'spatial turn' in missionary studies, but also calls for more attention

133 Fotiadis, "The strange power of maps," 16. 
to missionary cartography, a rather neglected field of study. ${ }^{134}$ It also underscores the fact that for missionary societies, maps matter.

\section{Acknowledgement}

We would like to thank Marco van Egmond for his advice on map projections, and the History Department of Utrecht University for financial support for researching this article, Martha Frederiks and the two anonymous referees of this article for their constructive comments on the first draft of this article, and Kate Delaney for editing the text. We would also like to acknowledge the kind cooperation of Mission Info Bank (especially of Loren Muehlius), Green Window Ministries, Far East Broadcasting Company, the Joshua Project and Rebecca Lewis for making their maps and charts available and allowing us to reproduce them.

134 Ruth Kark, "The contribution of nineteenth century Protestant missionary societies to historical cartography," Imago Mundi 45 (1993), 112-19. 